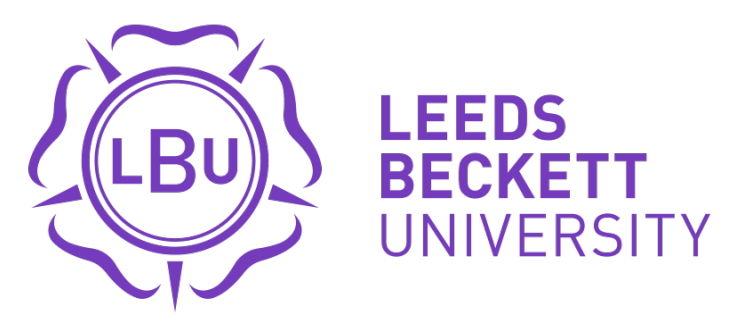

Citation:

Newman, S (2020) Reviewing school leadership : From psychology to philosophy. International Journal of Leadership in Education. ISSN 1360-3124 DOI: https://doi.org/10.1080/13603124.2020.1744734

Link to Leeds Beckett Repository record:

https://eprints.leedsbeckett.ac.uk/id/eprint/6630/

Document Version:

Article (Accepted Version)

This is an Accepted Manuscript of an article published by Taylor \& Francis in International Journal of Leadership in Education on 31st March 2020, available online: http://www.tandfonline.com/10.1080/13603124.2020.1744734

The aim of the Leeds Beckett Repository is to provide open access to our research, as required by funder policies and permitted by publishers and copyright law.

The Leeds Beckett repository holds a wide range of publications, each of which has been checked for copyright and the relevant embargo period has been applied by the Research Services team.

We operate on a standard take-down policy. If you are the author or publisher of an output and you would like it removed from the repository, please contact us and we will investigate on a case-by-case basis.

Each thesis in the repository has been cleared where necessary by the author for third party copyright. If you would like a thesis to be removed from the repository or believe there is an issue with copyright, please contact us on openaccess@leedsbeckett.ac.uk and we will investigate on a case-by-case basis. 


\title{
Reviewing school leadership: From psychology to philosophy
}

\author{
Stephen Newman
}

Carnegie School of Education, Leeds Beckett University, Leeds, United Kingdom

ORCiD: 0000-0002-2674-9154

Dr Stephen Newman,

Carnegie School of Education,

Leeds Beckett University,

Room 104, Carnegie Hall,

Headingley Campus,

Leeds, LS6 3QQ

s.n.newman@leedsbeckett.ac.uk (Corresponding author) 


\title{
Reviewing school leadership: From psychology to philosophy
}

\begin{abstract}
Arguably the notion of the school leader as the all-important person in school improvement in England still holds sway, despite the development of a huge range of leadership theories and perspectives which suggest a broader contextual approach may be appropriate. Reflecting on the development of a MA course in leadership and management, this paper argues that a philosophical approach based on the later work of Wittgenstein is helpful. The starting point for the approach used here is Wittgenstein's notion of language-games, which gives recognition to the many different views, descriptions, definitions, and theories of leadership. Informed by Wittgenstein's wider argument, it develops by bringing in the notions of family resemblance, social rules, and forms of life to suggest that Wittgenstein's account of meaning is able to move us towards a better understanding of the range of views about school leadership.
\end{abstract}

Key words: educational leadership; philosophy of education; Wittgenstein

\section{Introduction}

There have been many changes in the role of headteachers and other school leaders over the last 30 to 40 years in England - see Weindling (1992), Webb and Vulliamy (1996), Brundrett and Rhodes (2014), and Gilroy (2019). For example; whereas schools were once relatively straightforward to categorize, Courtney and Gunter (2015, p. 404) have recently identified 90 school types, with a concomitant increase in the variety of job titles that school leaders use (Department for Education, 2015, p. 4). The work of school leaders is now more complex and wide-ranging - their work is not just about children 
and the curriculum in any narrow sense (Chevaillier, 2006, p. 31) but also involves HR, policies, finance, employment law, building regulations, bid writing, and so on (Lazenby, McCulla, \& Marks, 2020, p. 3). It is still the case that 'Headteachers often feel that they are not on top of all the tasks expected of them' (Chevaillier, 2006, p. 31). When one adds to this mix the many interpretations of leadership, it comes as little surprise that some suggest that England's schools have a leadership recruitment crisis on their hands (Busby, 2019; The Future Leaders Trust, 2016).

Yet. at this time of rapid change, the role of the leader in schools has, it seems, become ever more important. The emphasis often seems to be on the personality and the psychology of the leader. In 2005, Simkins drew out what he regarded as some of the key ideas reflected in many aspects of thinking about, and the practice of, leadership in education, namely:

- that leadership resides in individuals

- that leadership is hierarchically based and linked to office

- that leadership occurs when leaders do things to followers

- that leadership is different from and more important than management

- that leaders are different

- that leaders make a crucial difference to organizational performance

- that effective leadership is generalizable. (Simkins, 2005, p. 11)

This approach seems to have persisted. It has been said that 'No matter the governing body, geographical region, or setting of an underperforming school, there is a common belief that the leader (singular) is solely responsible for changes to occur' (Denmark, 2012), and that 'there is not a single documented case of a school successfully turning around its pupil achievement trajectory in the absence of talented leadership' (Leithwood, Harris, \& Hopkins, 2008, p. 29). In 2009, Day et al. argued that: 
The research demonstrates that heads in more effective schools are successful in improving pupil outcomes through who they are - their values, virtues dispositions, attributes and competences - the strategies they use, and the specific combination and timely implementation and management of these strategies in response to the unique contexts in which they work. (Day et al., 2009, p. 1)

Perhaps because of the increase in demands on headteachers, and the increasing profile of school leaders, 'educational leadership and management has... become an established discipline with its own theories' (Bush, 2011, p. 15). Many different models and theories of leadership and management have been proposed; Zaccaro and Horn give a useful summary of many of them (2003, pp. 771-772), as do Bush and Glover (2003). Bush (2011, p. 13) draws attention to how many such models had their origins in industry and were later applied to educational settings (Bush, 2011, pp. 33-54). Parry and Bryman (2006, p. 448) consider that the trait approach dominated until late 1940s, followed by the leadership style approach to the late 1960s, the contingency approach until the early 1980s, followed by the New Leadership approach dominating the late 1990s, and then the post-charismatic and post-transformational approaches emerging in the late 1990s. Avolio, Walumbwa, and Weber (2009, p. 422) highlight how studies have moved away from focusing on a single leader and onto the study of followers, peers, supervisors and the context in which leadership takes place. Jensen (2020, p. 2) suggests that the 'theory movement' dominated school leadership research until the early 1970s but fell out of favor for concentrating too much on 'technical issues and administrative skills and for the lack of attention to values'. Perhaps for these reasons, one recent approach argues that 'leadership is no longer simply described as an individual characteristic or difference, but rather is depicted... as shared, relational, strategic, global, and a complex social dynamic' (Avolio et al., 2009, pp. 422-423), and James, Crawford, and Oplatka (2019) highlight the affective dimension to leadership. 
However, whether these broader notions of leadership have become influential in terms of school leadership is debatable (Leithwood, Harris, \& Hopkins, 2020; L. Thomas, Tuytens, Devos, Kelchtermans, \& Vanderlinde, 2020).

How can we make sense of such a 'morass of definitions, studies and theories' (Kelly 2008, p.774)? And how can they be applied, if at all, to leadership in schools? These questions came to the fore a few years ago when I was asked to write a new MA course in leadership and management for teachers and other education professionals who wished to undertake some professional development. The course would seek to attract a wide range of participants. These would include those who were working in this country, as well as students from other countries. Some would be current school leaders; others would be aspiring to become school leaders, whilst it was hoped that the course would also be attractive to those who were, or were seeking to become, leaders of subject departments or with pastoral responsibilities, or working in other educational and education-related settings. Given the wide-ranging backgrounds of the participants, and their differing expectations of the course, what approaches would be helpful? And how would any such approaches fit with different theories of leadership and management? And how too would they relate to the experiences of the course participants, considering that 'the field of leadership is littered with many examples of theories and models that have failed utterly when put to the test of solving leadershiprelated problems' (Zaccaro \& Horn, 2003, p. 770)? This disconnect between theory and practice was expressed by Gunter in the following terms when she commented that:

when the professionals I work with engage with critical policy ideas they tend to become very angry that leadership training has presented them with unworkable solutions and denied them access to more productive thinking" (Gunter, 2013, p. 225).

As Zaccaro and Horn argued (2003, p. 770), the gap between theory and practice has 
given rise to a range of popular literature offering 'single case studies, anecdotal evidence, and common sense reflections upon actual experiences' (2003, p. 770), as well as accounts they consider are based on 'fads' (2003, p. 779). It seemed doubtful that an approach that concentrated on giving an overview of numerous such accounts in detail would be valuable to postgraduate students, from many different contexts, often working as (or with experience of being) practitioners in schools but who were seeking a more critical perspective.

The many different theories of leadership and management are so well known that there is little need to summarize them here in much detail. But a detailed examination of them, it could be argued, might still be appropriate for postgraduate students, if only to examine the claim that 'the definition of leadership is arbitrary and very subjective' (Yukl, 2002, pp. 4-5 cited by Bush, 2011, p. 5). Similarly, MacBeath some years earlier considered that leadership to be a term:

full of ambiguity and a range of interpretations. It is a humpty dumpty word that can mean 'just what we want it to mean' (Humpty Dumpty, quoted in Alice in Wonderland). (MacBeath, 2003, p. 1)

What was needed, I decided, in designing and teaching the course, was an approach which more effectively synthesized theory and practice, which was capable of incorporating the richness of case studies, anecdotes and common sense reflections, and which was at the same time capable of providing a deeper understanding - what Zaccaro and Horn term a 'leadership theory-practice symbioses' (2003, p. 770). This led me to an alternative approach to studying leadership, influenced by some of those who had drawn on the later philosophy of Wittgenstein, such as Pondy (1978), Simkins (2005), Kelly (2008), and Marturano et al. (2010). One reason for adopting such an approach is expressed by Marturano et al. who considered that leadership theories 
typically lack an epistemological basis and arise from largely empirical studies. It is therefore an integral assumption of this paper that any epistemology presupposes a theory of meaning and that consequently a philosophical approach involving an account of meaning is appropriate.

\section{Wittgenstein}

In turning to consider the work of Wittgenstein, some introductory caveats are in order. First, it is important to distinguish between what are usually termed his early and late philosophies. Both examples of Wittgenstein's work used here (Philosophical investigations (Wittgenstein, 1967), henceforth PI, and On certainty (Wittgenstein, 1969), henceforth $O C$ ), are commonly agreed to be later works. ${ }^{1}$ In addition, it is not possible in one article to give more than an outline of some of the key themes of his later work, consisting as it does of an interconnecting web of ideas. As such, it is important to remember the need to see Wittgenstein's later philosophy as a coherent and wide-ranging whole (Keightley, 1976, p. 17).

Wittgenstein's later philosophy can be viewed as giving an account of meaning, as evidenced by the opening remarks in the Philosophical Investigations. It is in these remarks that Wittgenstein introduces the phrase 'language-game' $(P I, \S 7$, p. 5e). Wittgenstein (consistent with the approach he was adopting) did not tightly define the notion of language-game (PI, § 65, p. 31e) - see Gilroy (1996, p. 106) and Pondy (1978, p. 97) - but the notion of a language-game is the starting point for an account of meaning that can account for the diversity of meanings and their shifting nature $(O C, \S$ 63 , p. 10e). Wittgenstein's account stresses the social context and the conventional nature of language as opposed to searching for the general forms of propositions and language (PI, $\S 65$, p. 31e; $\S 81$, p.38e). Wittgenstein writes that although we $c a n$, if we 
so wish, tightly define a term, that is not a requirement for using it $(P I, \S 68, \mathrm{pp} .32 \mathrm{e}-$

33e). Taking as an example, 'games', Wittgenstein writes:

How should we explain to someone what a game is? I imagine that we should describe games to him, and we might add: "This and similar things are called 'games"'. And do we know any more about it ourselves? Is it only other people whom we cannot tell exactly what a game is?-But this is not ignorance. We do not know the boundaries because none have been drawn. To repeat, we can draw a boundary — for a special purpose. Does it take that to make the concept usable? Not at all! (Except for that special purpose.) (PI, § 69, p. 33e, emphases in original)

Wittgenstein argues that:

For a large class of cases - though not for all — in which we employ the word "meaning" it can be defined thus: the meaning of a word is its use in the language. (PI, § 43, p. 20e, emphasis in original)

Elsewhere he expresses it slightly differently:

A meaning of a word is a kind of employment of it.

For it is what we learn when the word is incorporated into our language. (OC, $\S 61$, p. 10e)

This leads to another important idea - namely that of 'family resemblance'. The use of the word 'games', considers Wittgenstein, reveals a 'complicated network of similarities overlapping and criss-crossing' (PI, § 66, p. 32e). We should not expect something to be common to all games; rather, games are related to each other, and the network of similarities can be characterized by the phrase 'family resemblances' $(P I, \S$ 67, p. 32e). To those that would suggest that their difference was something they all had in common, Wittgenstein replied that to argue this was merely playing with words (PI, $\S 67$, p. 32e). 
Given that the meanings of words are to be explained in terms of their uses, this then leads Wittgenstein to consider the rules which govern those uses $(O C, \S 62$, p. 10e; $P I, \S \S 80-88$, pp. 38e-42e). One important aspect to arise from Wittgenstein's consideration of rules is that they are founded on social purpose or customs (Gilroy, 1996, p. 109):

To understand a sentence means to understand a language. To understand a language means to be master of a technique. (PI, § 199, p. 81e)

What this shews is that there is a way of grasping a rule which is not an interpretation, but which is exhibited in what we call "obeying the rule" and "going against it" in actual cases. (PI, § 201, p. 81e, emphases in original)

The rules which provide that frame of reference for any particular language-game may be implicit or explicit. Sometimes they are just used; sometimes they need to be explained; meanings 'are rule and criteria dependent in subtle and complex ways' (Gilroy, 2012, p. 56). These 'elusive networks' (P. Thomas, Shah, \& Thornton, 2009, p. 15) of rules form the grammar of the language and, as Gilroy argues (1996, p. 108), provide a social rather than a logical necessity $(P I, \S \S 217-219, \mathrm{p} .85 \mathrm{e})$ :

Here the term "language-game" is meant to bring into prominence the fact that the speaking of language is part of an activity, or of a form of life. $(P I, \S 23, \mathrm{p} .11 \mathrm{e}$, emphases in original)

You must bear in mind that the language-game is so to say something unpredictable. I mean: it is not based on grounds. It is not reasonable or unreasonable.

It is there-like our life. $(O C, \S 559$, p. 73e)

How do we know if a language-game is being played correctly? For Wittgenstein, language is part of a social whole, consisting of both verbal and non-verbal behaviors in specific contexts, in particular times and places $(P I, \S 7$, p. $5 \mathrm{e} ; \S 23$, p. $11 \mathrm{e})$. It is that 
whole context or language-game that provides the frame of reference for deciding on the meaning of a particular linguistic or non-linguistic behavior (Berducci, 2004, p. 342). This then brings us to what might be termed Wittgenstein's descriptive account of meaning (Gilroy, 1996, p. 111). It is an account of meaning which can be thought of as

both fixed and relative, as are the purposes of games, depending on whether one's perspective is within or without that particular set of agreements. (Gilroy, 1996, p. 111)

For these reasons, it has been said (Smeyers \& Marshall, 1995, p. 130) that 'Wittgenstein's “theory” of meaning advocates neither a position of pure subjectivity nor of pure objectivity'. It thus avoids what might be termed the hard objectivity which locates meaning external to any context, but also avoids the subjectivity of the Alice in Wonderland perspective, that words can mean anything anyone wants them to mean.

\section{Leadership: From psychology to philosophy}

Why is this approach of value in thinking about school leadership? One reason is that by adopting this approach, we can move away from trying to identify supposed psychological characteristics of leadership (viewed as 'an act or process, over and above, or behind' (Malcolm, 1971, p. 387) their expression in behavior) where it seems we are 'trying to get hold of the mental process of understanding which seems to be hidden behind those coarser and therefore more readily visible accompaniments' $(P I, \S$ 153, p. 60e). Instead, we can move towards depicting leadership (as suggested previously) as a "complex social dynamic" (Avolio et al., 2009, p. 423), rather than trying to describe it simply in terms of 'an individual characteristic or difference' (Avolio et al., 2009, pp. 422-423). In addition, despite the fact that our 'epistemology seems to force us to agree on a conceptual definition of the term "leadership"' (Pondy, 
1978, p. 88, emphasis omitted), the Wittgensteinian approach

suggests that we begin to think of leadership, like language, as a collection of games with some similarities, but no single characteristic common to all of them. (Pondy, 1978, p. 97, emphasis in original)

When we begin to think of leadership in these ways, it helps us to embrace the variety of meanings, behaviors and uses of the term leadership that Pondy describes, and recognize that leadership has a social dimension; to recognize that it is a term that can be applied to a wide range of behaviors, and understand why current definitions too often seem unable to 'fully account for the diversity and divergence of interacting explanations' (Pondy, 1978, p. 88). It is also an approach that encourages us, indeed demands of us, to 'look and see' (PI, §66, p. 31e, emphasis in original). Rather than theorizing (cf. PI, §66, p. 31e), we could for example, 'be trying to document the variety of leadership strategies, rather than trying to collapse it into a few constraining categories' (Pondy, 1978, p. 90, emphasis in original), categories which, by emphasizing leadership style, often seem to emphasize a superficiality of approach. We could incorporate this with Gunter's view (a view expressed by others such as Kelly (2008, pp. 770-771) and Marturano et al. (2010) that we can use
philosophical thinking as a key methodology ... [which] combined with qualitative data from ethnographic work enables critical science to interplay thinking, data and theory bringing new insights. (Gunter, 2016, p. 175, emphases in original)

This is not, as Kelly suggests, to see leadership as concerned with linguistics (Kelly, 2008, p. 767). It is not sufficient to merely envisage leadership as a language-game, or a series of discrete language-games, for such an interpretation would fly in the face of the holistic description of meaning that Wittgenstein gives involving family resemblances and forms of life. Nor is the approach I am suggesting one which fits straightforwardly 
into that suggested by Marturano et al. (2010), who propose an 'analytical philosophical foundation to leadership studies' (Marturano et al., 2010, p. 60), seen as a process of clarifying the meaning of statements and concepts, and which 'emphasizes a clear, rigorous approach with particular weight being placed upon argumentation and evidence, avoidance of ambiguity, and attention to detail' (Marturano et al., 2010, p. 60). As we have seen, this approach might be needed in particular contexts and in particular circumstances, as a result of which, 'language - including talk about leadership - creates and institutionalizes those symbols as "fact-like"' (Marturano et al., 2010 , p. 62), but it is misleading to draw from that idea that the 'meaning of a word... is an objective one which is common to every speaker' (Marturano et al., 2010, p. 60, footnote 7).

Thus, contrary to the warnings of Bush, and also MacBeath to which reference was made earlier, although the term leadership has many meanings, those meanings are not arbitrary or subjective. It is not a word that can mean anything one wants it to mean. Rather, the perspective for which I have argued is in sympathy with that of Simkins (Simkins, 2005) which emphasizes the importance of context, of recognizing complexity (Simkins, 2005, p. 12) and where, 'in the leadership world, "making sense of things" is at least as important as "seeking what works" (Simkins, 2005, p. 10). Furthermore, it reminds us of the value of examining the specific contexts in which school leadership occurs (Dimmock, 2005, p. 82), as Greenhalgh (2015) argued. It is consistent too with seeing

our current public sector — and educational — world as one in which discourses are in contention, different accommodations are being reached in different contexts and these accommodations are changing over time in a very dynamic way. (Simkins, 2005, p. 14)

It also provides a practically relevant perspective that those postgraduate students 
mentioned earlier might find helpful in making sense of the policy environment that at times places expectations, tensions, and contradictions on school leaders (Simkins, 2005, p. 15). It sharpens our awareness and understanding of why it is that what, on the surface, appear to be similar activities may, in fact, be very different depending on their purpose and the detail of their practice. (Simkins, 2005, pp. 20-21)

Similarly, as Malcolm argued (Malcolm, 1993, p. 44), we can be alert to those occasions when the same word is used in different contexts but with different meanings, and when different words are used but mean the same thing (Pondy, 1978, p. 93). It is an approach which helps us, and school leaders, 'to deliberate on, and make sense of, the contingent unfolding of particular events' (Greenhalgh, 2015, pp. 207-208), moving away

from static lists of decontextualized skills to an emphasis on contextual relevance and specificity and the art of application in such context. (English, 2006, p. 466)

This being so, we can view different theories of, and perspectives on, leadership as offering descriptions of various language-games, embedded in a variety of social contexts (historical, geographical, occupational, and so on). In this sense, they can be interpreted as attempts to, as mentioned previously, 'document the variety of leadership strategies, rather than trying to collapse it into a few constraining categories' (Pondy, 1978, p. 90, emphasis in original), and even perhaps as examples of some of the qualitative approaches Gunter (2016, p. 175) enjoined. In such ways, we can become more acutely aware of similarities and differences between meanings in different contexts, the better to make sense of the different meanings of school leadership. It is in this light that we can view many recent contributions to the debate - for example Sarid (2020) who uses the notions of family resemblance and forms of life and points out, for 
example, that what counts as various skills 'can mean many different things from different cultural outlooks' (Sarid, 2020, p. 7), just as what is to count as school improvement can be interpreted in many different ways (Waite, 2002). We can embrace the notion (or rather notions) of leadership as social constructs (Jensen, 2020, p. 3). Wittgenstein's approach leads us away from what Leithwood et al. (2008, p. 8) call the superficial view, namely that 'context is everything', and away too from the idea that all Wittgenstein's perspective does is to explain that leadership may mean different things in different contexts, and that misunderstandings may arise between those in different contexts. The recognition that that is so is only the starting point for Wittgenstein's investigations into meaning. His approach reminds us that it is 'fool's errand' (Murphy, 2005, p. 174) to try to, as Marturano et al. (2010, p. 61) put it, pull the meanings of terms such as leadership, and leadership behavior out of the contexts which give them life and in which they have meaning

\section{Note}

1. As is customary, references to Wittgenstein's work are abbreviated as shown, with specific paragraphs indicated $\S$, and page numbers shown with the suffix e indicating translations into English where appropriate.

\section{References}

Avolio, B. J., Walumbwa, F. O., \& Weber, T. J. (2009). Leadership: Current theories, research, and future directions. Annual Review of Psychology, 60, 421-449. doi:10.1146/annurev.psych.60.110707.163621

Berducci, D. F. (2004). Vygotsky through Wittgenstein: A new perspective on Vygotsky's developmental continuum. Theory and Psychology, 14(3), 329-353. doi:10.1177/0959354304043639

Brundrett, M., \& Rhodes, C. (2014). Researching educational leadership and management: Methods and approaches. London: Sage. 
Busby, E. (2019, 3 May). Number of schools failing to recruit senior leaders rises to record high, survey suggests. Independent. Retrieved from https://www.independent.co.uk/news/education/education-news/teachershortage-school-head-staff-recruit-retention-naht-headteacher-a8896751.html

Bush, T. (2011). Theories of educational leadership and management (4 ed.). London: Sage.

Bush, T., \& Glover, D. (2003). School leadership: Concepts and evidence. Nottingham: National College for School Leadership.

Chevaillier, T. (2006). The new roles of secondary school head teachers: Secondary education in the 21st century (ED-2009/WS/57). Retrieved from Paris: https://unesdoc.unesco.org/ark:/48223/pf0000149057_eng

Courtney, S. J., \& Gunter, H. M. (2015). Get off my bus! School leaders, vision work and the elimination of teachers. International Journal of Leadership in Education: Theory and Practice, 18(4), 395-417. doi:10.1080/13603124.2014.992476

Day, C., Sammons, P., Hopkins, D., Harris, A., Leithwood, K., Gu, Q., . . Kington, A. (2009). The impact of school leadership on pupil outcomes: Final report Retrieved from https://dera.ioe.ac.uk/11329/1/DCSF-RR108.pdf:

Denmark, V. (2012). Transformational leadership - A matter of perspective. Retrieved from http://www.advanc-ed.org/source/transformational-leadership-matterperspective

Department for Education. (2015). National standards of excellence for headteachers: Departmental advice for headteachers, governing boards and aspiring headteachers. London: Department for Education Retrieved from https://assets.publishing.service.gov.uk/government/uploads/system/uploads/atta chment_data/file/396247/National_Standards_of_Excellence_for_Headteachers. pdf

Dimmock, C. (2005). The leadership of multi-ethnic schools: What we know and don't know about values-driven leadership. Educational Research and Perspectives, 32(2), 80-96. Retrieved from http://citeseerx.ist.psu.edu/viewdoc/download?doi=10.1.1.471.9313\&rep=rep1\& type $=$ pdf 
English, F. W. (2006). The unintended consequences of a standardized knowledge base in advancing educational leadership preparation. Educational Administration Quarterly, 42(3), 461-472. doi:10.1177/0013161X06289675

Gilroy, P. (1996). Meaning without words: Philosophy and non-verbal communication. Aldershot: Avebury.

Gilroy, P. (2012). Lifelong learning: A language game in search of its rules. In D. N. Aspin, J. D. Chapman, K. Evans, \& R. Bagnall (Eds.), Second international handbook of lifelong learning. Part 1 (pp. 51-59). London: Springer.

Gilroy, P. (2019). Editorial: all change? Journal of Education for Teaching, 45(1), 1. doi:10.1080/02607476.2019.1550601

Greenhalgh, T. (2015). Higher education governance as language games: A Wittgensteinian case study of the breakdown of governance at the London School of Economics 2004-2011. Higher Education Quarterly, 69(2), 193-213. doi:10.1111/hequ.12064

Gunter, H. M. (2013). On not researching school leadership: the contribution of S. J. Ball. London Review of Education, 11(3), 218-228. doi:10.1080/14748460.2013.840982

Gunter, H. M. (2016). An intellectual history of school leadership practice and research. London: Bloomsbury.

James, C., Crawford, M., \& Oplatka, I. (2019). An affective paradigm for educational leadership theory and practice: connecting affect, actions, power and influence. International Journal of Leadership in Education, 22(5), 617-628. doi:10.1080/13603124.2018.1481536

Jensen, R. (2020). Professional development of school leadership as boundary work: patterns of initiatives and interactions based on a Norwegian case. International Journal of Leadership in Education. Advance online publication. doi:10.1080/13603124.2020.1716998

Keightley, A. (1976). Wittgenstein, Grammar and God. London: Epworth Press.

Kelly, S. (2008). Leadership: A categorical mistake? Human Relations, 61(6), 763-782. doi:10.1177/0018726708092403

Lazenby, S., McCulla, N., \& Marks, W. (2020). The further professional development of experienced principals. International Journal of Leadership in Education. Advance online publication. doi:10.1080/13603124.2020.1716999 
Leithwood, K., Harris, A., \& Hopkins, D. (2008). Seven strong claims about successful school leadership. School Leadership and Management, 28(1), 27-42. doi:10.1080/13632430701800060

Leithwood, K., Harris, A., \& Hopkins, D. (2020). Seven strong claims about successful school leadership revisited. School Leadership \& Management, 40(1), 5-22. doi:10.1080/13632434.2019.1596077

MacBeath, J. (2003). The alphabet soup of leadership. Inform, (2), 1-15. Retrieved from https://www.educ.cam.ac.uk/networks/lfl/about/inform/PDFs/InForm_2.pdf

Malcolm, N. (1971). The myth of cognitive processes and structures. In T. Mischel (Ed.), Cognitive development and epistemology (pp. 385-392). New York and London: Academic Press.

Malcolm, N. (1993). Wittgenstein: A religious point of view? London: Routledge.

Marturano, A., Wood, M., \& Gosling, J. (2010). Leadership and language games. Philosophy of Management, 9(1), 59-83. doi:10.5840/pom20109118

Murphy, J. (2005). Unpacking the foundations of ISLLC Standards and addressing concerns in the academic community. Educational Administration Quarterly, 41(1), 154-191. doi:10.1177/0013161X04269580

Parry, K. W., \& Bryman, A. (2006). Leadership in organizations. In S. R. Clegg, C. Hardy, T. B. Lawrence, \& W. R. Nord (Eds.), The SAGE Handbook of Organization Studies (pp. 447-468). London: Sage.

Pondy, L. R. (1978). Leadership is a language game. In J. McCall, M. W., \& M. M. Lombardo (Eds.), Leadership: where else can we go? (pp. 87-99). Durham, NC: Duke University Press.

Sarid, A. (2020). The radical critique of culture and social justice educational leadership. International Journal of Leadership in Education. Advance online publication. doi:10.1080/13603124.2020.1717000

Simkins, T. (2005). Leadership in education: 'What works' or 'What makes sense'? Educational Management Administration and Leadership, 33(1), 9-26. doi:10.1177/1741143205048168

Smeyers, P., \& Marshall, J. D. (1995). The Wittgensteinian frame of reference and philosophy of education at the end of the twentieth century - An introduction to philosophy and education: Accepting Wittgenstein's challenge. Studies in Philosophy and Education, 14(2-3), 127-159. doi:10.1007/BF01074118 
The Future Leaders Trust. (2016). Heads Up: Meeting the challenges of headteacher recruitment. London: The Future Leaders Trust.

Thomas, L., Tuytens, M., Devos, G., Kelchtermans, G., \& Vanderlinde, R. (2020). Transformational school leadership as a key factor for teachers' job attitudes during their first year in the profession. Educational Management Administration and Leadership, 48(1), 106-132. doi:10.1177/1741143218781064

Thomas, P., Shah, A., \& Thornton, T. (2009). Language, games and the role of interpreters in psychiatric diagnosis: A Wittgensteinian thought experiment. Journal of Medical Humanities, 35, 13-18. doi:10.1136/jmh.2008.000422

Waite, D. (2002). Big Change Question: Is the role of the principal in creating school improvement over-rated? Journal of Educational Change, 3, 161-165. doi:10.1023/A:1016520313112

Webb, R., \& Vulliamy, G. (1996). The changing role of the primary-school headteacher. Educational Management and Administration, 24(3), 301-315. doi:10.1177/0263211X9602400307

Weindling, D. (1992). Marathon running on a sand dune: The changing role of the headteacher in England and Wales. Journal of Educational Administration, 30(3), 63-76. doi:10.1108/09578239210014324

Wittgenstein, L. (1967). Philosophical investigations (G. E. M. Anscombe, Trans. 3 ed.). Oxford: Basil Blackwell.

Wittgenstein, L. (1969). On certainty (D. Paul \& G. E. M. Anscombe, Trans. G. E. M. Anscombe \& G. H. von Wright Eds.). Oxford: Basil Blackwell.

Yukl, G. A. (2002). Leadership in organizations (5 ed.). Upper Saddle River, NJ: Prentice Hall.

Zaccaro, S. J., \& Horn, Z. N. J. (2003). Leadership theory and practice: Fostering an effective symbiosis. The Leadership Quarterly, 14, 796-806. doi:10.1016/j.leaqua.2003.09.009 